\title{
触 New Disease Reports \\ First report of Potato aucuba mosaic virus in Solanum jasminoides in the United Kingdom
}

\author{
A. Fox ${ }^{1 *}$, A. Fowkes ${ }^{1}$, A. Buxton-Kirk ${ }^{1}$, L. Jackson ${ }^{1}$, S. Forde ${ }^{1}$, R. Ward ${ }^{1}$, A. Maclvor ${ }^{2}$, V. Harju ${ }^{1}$, A. Skelton ${ }^{1}$ and I. Adams $^{1}$ \\ ${ }^{1}$ Fera Science Ltd, Sand Hutton, York, YO41 1LZ, UK; ${ }^{2}$ Plant Health and Seeds Inspectorate, Animal and Plant Health \\ Agency, Sand Hutton, York, YO41 1LZ, UK
}

*E-mail: adrian.fox@fera.co.uk

Received: 11 Oct 2016. Published: 21 Dec 2016.

In March 2016, samples of eight Solanum jasminoides plants were submitted to Fera Science Ltd., from a nursery in southeast England. The samples were sent to the laboratory as part of plant health monitoring for latent viral diseases, although they were exhibiting slight leaf mottling. Samples were tested by ELISA for the presence of Tobacco mosaic virus, Tomato black ring virus, Tomato mosaic virus, Tomato spotted wilt virus and potyviruses (DSMZ, Germany), Alfalfa mosaic virus, Impatiens necrotic spot virus, Potato virus $Y$ and Tomato black ring virus (Bioreba, Switzerland), Cucumber mosaic virus and Tobacco ringspot virus (Agdia, USA), Tobacco etch virus and Tomato ringspot virus (Loewe Biochemica, Germany) and begomoviruses (Neogen Europe, Scotland). In each case the samples were negative. Additionally, samples were screened for the presence of pospiviroids using generic RT-PCR primers (Mumford et al., 2000; Verhoeven et al., 2004) for which they also tested negative.

To provide a broad non-targeted screen for viral pathogens, samples were mechanically inoculated onto Chenopodium quinoa, Nicotiana benthamiana $N$. hesperis and $N$. occidentalis $\mathrm{P} 1$. Plants of $N$. hesperis developed systemic chlorotic spotting (Fig. 1) and plants of $N$. occidentalis P1 developed necrotic local lesions (Fig. 2) ten days after inoculation. Symptomatic leaf samples were collected from the inoculated plants and screened using next generation sequencing (NGS; Adams et al., 2014). A putative genome of a potexvirus was recovered from the sample having $90 \%$ similarity to that of Potato aucuba mosaic virus (PAMV) (GenBank Accession No. S73580). A neighbour-joining tree constructed using RdRp proteins from the recovered sequence (KY123701), PAMV (S73580) and related potexviruses identified the current sequence as PAMV (Fig. 3). To confirm the finding, the mechanical inoculations were repeated and PAMV symptoms were reproduced. Additionally, Capsicum аппиит plants were also inoculated, which exhibited systemic necrotic lesions/patches associated with PAMV.
All the symptomatic sap-inoculated plants, including the inoculated $N$. occidentalis sample used in NGS, were also tested by DAS ELISA (DSMZ, Germany, reference number AS-1075) with a positive control (reference number PC-0007) for the presence of PAMV, with positive results.

PAMV has been previously recorded affecting potato in the UK (Brenchley \& Wilcox, 1979) but it is considered to be uncommon. This finding in $S$. jasminoides is believed to be the first record of a naturally occurring infection of PAMV outside of potato.

\section{Acknowledgements}

This testing was funded through the Defra-Fera Long Term Service Agreement.

\section{References}

Adams IP, Skelton A, Macarthur R, Hodges T, Hinds H, Flint L, Nath PD, Boonham N, Fox A, 2014. Carrot yellow leaf virus is associated with carrot internal necrosis. PLOS ONE 9, e109125.

http://dx.doi.org/10.1371/journal.pone.0109125

Brenchley GH, Wilcox, HJ, 1979. Potato Diseases. Her Majesty's Stationery Office, London, United Kingdom. ISBN 0112403301.9780112403302

Mumford RA, Walsh, K, Boonham N, 2000. A comparison of molecular methods for the routine detection of viroids. EPPO Bulletin 30, 431-435. http://dx.doi.org/10.1111/j.1365-2338.2000.tb00924.x

Verhoeven JThJ, Jansen CCC, Willemen TM, Kox LFF, Owens RA, Roenhorst JW, 2004. Natural infections of tomato by Citrus exocortis viroid, Columnea latent viroid, Potato spindle tuber viroid and Tomato chlorotic dwarf viroid. European Journal of Plant Pathology 110, 823-831. http://dx.doi.org/10.1007/s10658-004-2493-5
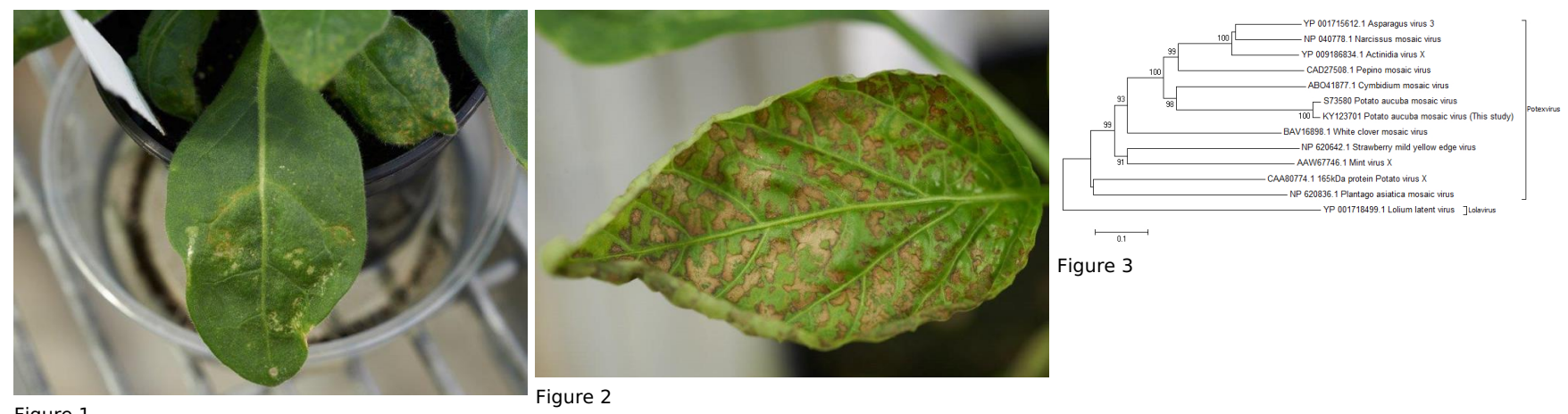

Figure 1

Figure 2

To cite this report: Fox A, Fowkes A, Buxton-Kirk A, Jackson L, Forde S, Ward R, Maclvor A, Harju V, Skelton A, Adams I, 2016. First report of Potato aucuba mosaic virus in Solanum jasminoides in the United Kingdom. New Disease Reports 34, 32. http://dx.doi.org/10.5197/j.2044-0588.2016.034.032 